\title{
Front Matter: Volume 11542
}

"Front Matter: Volume 11542," Proc. SPIE 11542, Counterterrorism, Crime Fighting, Forensics, and Surveillance Technologies IV, 1154201 (9 October 2020); doi: $10.1117 / 12.2584648$

SPIE. Event: SPIE Security + Defence, 2020, Online Only 


\title{
Counterterrorism, Crime Fighting, Forensics, and Surveillance Technologies IV
}

\author{
Henri Bouma \\ Radhakrishna Prabhu \\ Robert J. Stokes \\ Yitzhak Yitzhaky \\ Editors
}

\section{1-25 September 2020 \\ Online Only, United Kingdom}

Sponsored by

SPIE

Cooperating Organisations

European Optical Society

Cranfield University (United Kingdom)

Technology Scotland (United Kingdom)

Visit Scotland (United Kingdom)

CENSIS (United Kingdom)

Published by

SPIE 
The papers in this volume were part of the technical conference cited on the cover and title page. Papers were selected and subject to review by the editors and conference program committee. Some conference presentations may not be available for publication. Additional papers and presentation recordings may be available online in the SPIE Digital Library at SPIEDigitalLibrary.org.

The papers reflect the work and thoughts of the authors and are published herein as submitted. The publisher is not responsible for the validity of the information or for any outcomes resulting from reliance thereon.

Please use the following format to cite material from these proceedings:

Author(s), "Title of Paper," in Counterterrorism, Crime Fighting, Forensics, and Surveillance Technologies IV, edited by Henri Bouma, Radhakrishna Prabhu, Robert J. Stokes, Yitzhak Yitzhaky, Proceedings of SPIE Vol. 11542 (SPIE, Bellingham, WA, 2020) Seven-digit Article CID Number.

ISSN: 0277-786X

ISSN: 1996-756X (electronic)

ISBN: 9781510638976

ISBN: 9781510638983 (electronic)

Published by

SPIE

P.O. Box 10, Bellingham, Washington 98227-0010 USA

Telephone +1 3606763290 (Pacific Time) · Fax +1 3606471445

SPIE.org

Copyright (c) 2020, Society of Photo-Optical Instrumentation Engineers.

Copying of material in this book for internal or personal use, or for the internal or personal use of specific clients, beyond the fair use provisions granted by the U.S. Copyright Law is authorized by SPIE subject to payment of copying fees. The Transactional Reporting Service base fee for this volume is $\$ 21.00$ per article (or portion thereof), which should be paid directly to the Copyright Clearance Center (CCC), 222 Rosewood Drive, Danvers, MA 01923. Payment may also be made electronically through CCC Online at copyright.com. Other copying for republication, resale, advertising or promotion, or any form of systematic or multiple reproduction of any material in this book is prohibited except with permission in writing from the publisher. The CCC fee code is $0277-$ $786 \mathrm{X} / 20 / \$ 21.00$.

Printed in the United States of America by Curran Associates, Inc., under license from SPIE.

Publication of record for individual papers is online in the SPIE Digital Library.

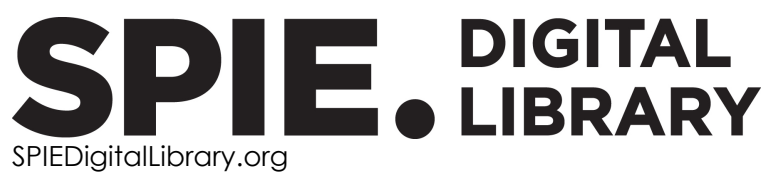

Paper Numbering: Proceedings of SPIE follow an e-First publication model. A unique citation identifier (CID) number is assigned to each article at the time of publication. Utilization of CIDs allows articles to be fully citable as soon as they are published online, and connects the same identifier to all online and print versions of the publication. SPIE uses a seven-digit CID article numbering system structured as follows:

- The first five digits correspond to the SPIE volume number.

- The last two digits indicate publication order within the volume using a Base 36 numbering system employing both numerals and letters. These two-number sets start with $00,01,02,03,04$, 05, 06, 07, 08, 09, OA, OB ... 0Z, followed by 10-1Z, 20-2Z, etc. The CID Number appears on each page of the manuscript. 


\section{Contents}

\section{SURVEILLANCE}

1154204 Deep learning-based drone detection in infrared imagery with limited training data [1 1542-1]

$1154205 \quad$ Visible to infrared transfer learning as a paradigm for accessible real-time object detection and classification in infrared imagery [11542-2]

1154206 A scoring algorithm for abnormal traveller behaviour in border crossing areas [11542-3]

$1154207 \quad$ Multi-user authorization for simultaneous collaborative situation analysis workspaces using XACML [1 1542-4]

1154208 Mashup tools for big data analysis in maritime surveillance [1 1542-5]

IDENTIFICATION AND AUTHENTICATION

11542 OA Anonymized person re-identification in surveillance cameras [11542-7]

11542 OC Document anonymization for border guards and immigration services [11542-9]

\section{CBRNE AND SPECTROSCOPY I}

11542 OD Electrochemiluminescence detection of methamphetamine in biological matrices [11542-10]

11542 OE Detection of explosives by ultrasonic spectrum upon pulsed laser initiation [1 1542-11]

11542 OF A proof-of-concept of smart lightweight cone for explosive ordnance mitigation in nonpermissive operating environment [11542-12]

$11542 \mathrm{OH} \quad$ Preliminary parameter studies to form pellets of hard materials for optical constants derived via single-angle reflectance spectroscopy [11542-14]

\section{CBRNE AND SPECTROSCOPY II}

11542 OJ Portable aerosol collector with liquid circulation mounted on a drone [11542-16] 
11542 OK About impurities in cyclotrhylmethylentrinitramine and the possibility of detecting its vapors [11542-17]

\section{BORDER SECURITY}

11542 OL Design of x-ray backscatter imaging system for vehicle detection [1 1542-18]

11542 ON Detecting migrant vessels in the Cyprus region using Sentinel-1 SAR data [1 1542-20]

POSTER SESSION

$1154200 \quad$ THz imaging with spectral resolution for identification of traces of explosives [11542-21]

$115420 Q \quad$ Investigations of hollow-core photonic crystal fibres (HC-PCF) for trace explosive vapour detection [11542-23] 